\title{
Enhancing Students' Writing Skill by Using Mind Mapping
}

\author{
Siti Karminah, Joko Nurkamto, Martono \\ English Education Department \\ Teacher Training and Education Faculty \\ Sebelas Maret University of Surakarta
}

Email: karminasiti@gmail.com

\begin{abstract}
The objectives of this thesis are to identify whether or not mind mapping technique can improve students' writing skill and to identify the class climate when mind mapping is used in teaching learning process. The action research was conducted from August to September 2012 and was carried out in two cycles to 34 students of a Junior High School in Jaten, Karanganyar. The research findings show that mind mapping technique could improve the students' writing skill. It can be seen from the score of pre-test, first post-test and second post-test, that is 52.32, 67.97, and 76.50. Class climate also improved when mind mapping was used in teaching learning process. Therefore, mind mapping can be used as alternative technique to improve the students' writing skill.
\end{abstract}

Keywords: writing, mind mapping

\section{INTRODUCTION}

Writing skill is an ability to express one's idea into letters, words and then sentences by considering several linguistics aspects such as content, grammar, vocabulary, organization, and mechanics. Based on National Education Ministry Regulation (2006: 25), the students of Junior High School must be able to express meaning in the written text in the form of simple transactional and interpersonal in formal or informal way in the form of recount, narrative, descriptive, and report in daily life. The ideal condition of writing skill is that the students of eight grades in Junior High School in Jaten Karanganyar can produce texts in good content and organization; using appropriate vocabulary; correct grammar and mechanics.

Based on the pre-research done in the eighth grade of a Junior High School in Jaten, Karanganyar. on July 2012, the researcher found problems dealing with their low writing skill. The mean score just got 52.32 and it is still under Minimum Required Standard (KKM) which is 70.00 .

In addition, the result of test, interviews and questionnaire showed that the students had difficulty in: (1) developing the idea; (2) using appropriate words to make sentences; (3) writing grammatically correct sentences; (4) organizing the text; (5) writing a text with correct punctuation, paragraphing and capitalization.

Then, based on the preliminary classroom observation, I found out that: (1) the students did not pay attention to the lesson; (2) the students were not active in teaching learning process; (3) the students were not interested in the lesson. They students were reluctant to write; (4) the class was not alive. English lesson was taught using teacher-centred approach; students usually sit, listen, and hopefully learn. 
To cope with the problems in the teaching writing, the researcher used mind mapping in teaching writing skill. The objectives of the research are to identify whether or not mind mapping technique can improve students' writing skill and to identify the effectiveness of mind mapping in teaching learning process.

Mind mapping was introduced by Buzan Tony in 1960s. Mind mapping is an outlining technique developed based on the way of how the brain works. The brain often recalls information in form of pictures, symbols, sounds, shapes, and feeling. Mind mapping uses those visual and sensory reminders in pattern to connect ideas. It can generate original ideas and easy recall (DePorter, 2005: 152).

Wycoff (2003: 83) states mind mapping is a good way to produce and organize the idea the idea before start to write. The difficulties in writing know what we are going to write, what the theme is, and how to start it. Through mind mapping, theme has been spelled out by the other theme branches so that become ideas promoter in writing. Mind mapping is a creative way for individual students to generate ideas, record learning, or plan a new project. Besides, asking the students to create a mind maps enables them to identify clearly and creatively what they have learned or what they are planning (Silberman, 1996: 59).

Harris (1993: 49) states that mind mapping is another form of diagram that incorporates a controlled type of brainstorming. Through mind mapping, the students, students' limitation of vocabulary can be reduced by applying brainstorming technique. Brainstorming can be done in many ways as long as the purpose is to make the students get their ideas out.
Steele (2005) said that mind mapping work as well as their visual design enables students to see relationship between ideas, encourages them to group certain ideas together as they proceed. Radial pattern outlining in mind mapping helps the students to see how ideas are connected. They can see the relationship among the ideas which have related with connective lines. Therefore, they can arrange their idea orderly and avoid rewriting similar ideas because they can see which ideas which have been written and which are not.

In addition, mind mapping was created based on the activity that most students do before writing that is imagination. The employing of image, symbols, colour and other graphics devices to stimulate the idea, giving impression make mind map able to generate original ideas and easy recall. The using of picture or image and colour in mind mapping can capture the students' interest and motivation to learn and lessen the students' boredom. Through mind mapping, the process to connect and analyze the ideas is clear. Thus mind mapping can concentrate the students' attention, improve the students' comprehension, amuse the writers and flexible to apply. Mind map work especially well when created in groups, since the discussion aids the production of ideas and makes the task livelier and more enjoyable.

The use of keywords in mind mapping also develops the students' awareness of using correct grammar which makes good effect in their writing. The mechanism such as spelling and capitalization letter can also be improved by mind mapping.

\section{RESEARCH METHODS}

The research was conducted at the eighth grade of students at Junior High in 
Jaten Karanganyar in the academic year of $2012 / 2013$. The research was started from August 2012 to September 2012. The data were taken from some sources such as observation, interview, questionnaire, photograph, diary, field note and tests.

The techniques for collecting the data used in this research are observational and non-observational techniques. The observational technique included classroom observation, field notes, diary and photographs (Burn, 2001:87-101). Meanwhile, the observational technique included writing test, interviews, and questionnaire.

The process of data analysis was conducted using qualitative and quantitative technique. The qualitative data such as the result of observation, interview, field notes, diary and questionnaire were analyzed using qualitative technique. Burns (2001: 157 160) states that there are five stages to analyze the qualitative data. The stages are assembling the data, coding the data, comparing the data, building meaning and interpretation, and reporting the outcome. Meanwhile, the quantitative data were analyzed using quantitative technique. The data was gained from the comparison of mean score the test among pre-test, post-test 1 and post-test 2 .

\section{RESEARCH FINDINGS AND DISCUSSIONS}

I did pre-test in order to get the details problem on students' skill of writing. The means score of pre-test was 52.32 and it was lower than minimum required standard of learning competence which was 70.00. Based on the observation and pre-test, it could be identified that the students' writing skill should be improved. I used mind mapping as the technique to teach writing.
After finding the problems, I made a plan to teach writing in cycle 1 . I prepared materials from internet, syllabus and relevant books. I planned four meetings in cycle 1 . Time for each meeting was 2 x 40 minutes. The material for cycle 1 was about pets such as cat, marmot, hamster and rabbit. During the research, I made some observation to the teaching learning process. After analyzing the observation result in cycle 1 , I did reflection in order to evaluate the teaching and learning process. I found the students' progress in students' writing. It could be seen by comparing the result of the pre-test and post-test during the implementation of the action. The mean score of the post-test in cycle 1 was 67.97 . It was better than the mean score of the pretest which was 52.32. Beside the improvement of students' writing score, there were also some improvements in the students' attitude toward writing lesson. The students were more interested to the lesson, paid attention to the lesson, and more active in the class.

Based on the result of cycle 1, I realized that there were improvements of the students' writing skill, but I still found some problems faced by the students. The problems were: (1) the students had difficulty in writing supporting details; (2) they wrote sentences with illogical sequencing; (3) Some students still wrote with inappropriate vocabulary; (4) they still made frequent error in word order, tenses, pronoun and (5) they were confused using punctuation and capitalization. Dealing with the problems in cycle 1 , I revised the plans. The revised plan was about training more the students to write and made some exercises to improve their ability in each aspect.

The action plan for cycle 2 was arranged after reflecting the observation 
result in cycle 1 . The planning for cycle 2 was making lesson plan, preparing hand out or worksheet. Cycle 2 also conducted in four meetings; three meetings for classroom discussion and activities using mind mapping and one meeting for post-test. Each meeting consisted of three parts namely: opening, main activity, and closing the class. The topic for cycle 2 was describing people, such as famous person, favourite teacher and my family.

After observing the teaching learning process in cycle 2 , it was assumed that the teaching learning process by using mind mapping ran well. The class climate was alive because students paid attention to the lesson and active in teaching learning process. Moreover, the post test of cycle 2 showed some improvements. The mean score of the post-test 1 was 67.97 and the mean score of the post-test in cycle 2 was 76.50. The improvement involved some indicators such as: (1) providing the supporting details of the idea; (2) writing grammatically correct sentences; (3) using appropriate words to make sentences; (4) creating well-organized text; (5) using appropriate mechanics to accomplish the purpose of the text. In detail, the students' achievement of each writing aspects in pretest, post test 1 and post test 2 can be seen in table 1. contribution toward students' writing skill. Those findings are discussed as follow:

1) Mind mapping can improve students' writing skill.

Mind mapping as the technique of teaching writing could improve students' writing skill. The improvements included: (1) students could providing supporting details of idea; (2) the students could create well-organized text; (3) the students could use appropriate words to make sentences; (4) the students write grammatically correct sentences; (5) the students use appropriate mechanics to accomplish the purpose of the text. This finding was supported by the result of post test 2 score that higher than passing grade which is 70.00 .

The findings supported by Wycoff (2003: 84) states mind mapping is a good way to produce and organize the idea the idea before start to write. The difficulties in writing know what we are going to write, what the theme is, and how to start it. Through mind mapping, theme has been spelled out by the other theme branches so that become ideas promoter in writing. Besides, in the mind mapping concept, there are some brunches and sub brunch which are used to assemble the related ideas. After the idea has poured in the keyword of mind mapping, the students should think about overall structure of the mind map to decide

Table 1. Pre-test, Post-Test 1, Post-test 2

\begin{tabular}{ccccc}
\hline No. & Aspects & Pre-test & $\begin{array}{c}\text { Score } \\
\text { Post test } 1\end{array}$ & Post test 2 \\
\hline 1. & Content & 17.16 & 20.38 & 22.35 \\
2. & Organization & 10.72 & 13.88 & 15.96 \\
3. & Vocabulary & 11.10 & 13.94 & 15.83 \\
4. & Language Use & 10.28 & 16.49 & 18.58 \\
5. & Mechanics & 3.06 & 3.28 & 3.79 \\
& Total Score & 53.32 & 67.97 & 76.50 \\
\hline
\end{tabular}

Based on the result of cycle 1 and cycle 2 , it could be concluded that mind mapping gave the best way to present their point in order that their idea could sequence logically. 
Then, the organized mind maps would help them in writing the ideas logically in their text.

The students' limitation of vocabulary could be reduced by applying brainstorming through mind mapping. Harris (1993: 49) defines mind mapping as another form of diagram that incorporates a controlled type of brainstorming. Through mind mapping, the students, students' limitation of vocabulary can be reduced by applying brainstorming. He added that the brainstorm activity before making mind map stimulated the students to enrich their vocabulary which could help find effective word choice for their essay later. Then the abundance of vocabulary would give good affect in writing.

In language use aspect, the students' understanding about grammar increased. The use of keywords in mind mapping was able to develop the students' awareness of using grammatically correct in their text. Ingemann (2008) said that mind mapping is one of the best methods to optimize one's learning capacities and understanding of how the elements of complex structures are connected.

Mind mapping made students became aware of the spelling, capitalization, and punctuation of their essay. The sixth step of mind mapping was continuation. The further writing activities could be improved here. The students should edit the mechanic of their writing. Langan (2000: 26) states that editing is to edit-check for and correcterrors in grammar, punctuation, and spelling. Then, According to Tony Clelford (2002), mind mapping can help revision even if your course is conventional.

2) Mind mapping improved class climate.

The research findings show that mind mapping as technique in teaching writing was able to improve class climate. It can be seen as follow: (1) the students were interested to the lesson; (2) they were active in teaching learning process; (3) they were eager to write; (4) the teaching learning process was alive; (5) students have good writing habit.

These findings are supported by Nunan (1996: 200) who says visualization which uses sense of sight help to supplement the input provided by commercial and teacher-produced material, they can help to stimulate motivation and interest. Mind mapping uses visualization pattern, that is was a result of combination of image, color, some keyword, so it was interesting for students.

Mind mapping made students become active. In writing class, students worked in group in doing the task of mind mapping. Group discussion in writing class made the students active in discussing the topic with their group. As Steele (2005) stated that mind map work especially well when created in groups, since the discussion aids the production of ideas.

The students were eager to write. The attractiveness of mind mapping features such as picture; symbol; colour and line; and exercises since the teaching learning process, make the students enjoy doing the task of writing. After the research, the students never complained again, when the teacher asked them to write. They were eager to write after mind mapping was implemented in the teaching learning process of writing.

The teaching learning process was alive. The using of mind mapping technique in the writing class makes the process of teaching learning process alive. During the lesson, the teaching learning process was conducted in group work. When they found some difficulties or problem in their task, they asked the teacher to get the better 
solution. Then in stage of feedback, the students could share the result of their group work to other works. Other group could give comment or made some correction with the group presented. In this situation, the students did the task their selves and the teacher facilitated them in teaching learning process. It is really, there is good interaction between students and teacher. The students really think and learn the lesson, not just listen to the teacher explanation.

The students have good writing habit. After implementation of mind mapping technique, they had better habit in writing. Mind mapping made the students accustomed to make a plan before they write.

\section{CONCLUSIONS AND SUGGESTIONS}

It can be concluded that mind mapping can improve the students' writing skill. The improvement can be identified from their writing result. The mean score of pre-test is 52.32 while the mean score of post-test 1 and post-test 2 is 67.97 and

76.50. The students' writing skill improvement involves: (1) providing the supporting details of the idea; (2) writing grammatically correct sentences; (3) using appropriate words to make sentences; (4) creating well-organized text; (5) using appropriate mechanics to accomplish the purpose of the text.

Besides, mind mapping technique also improved class climate. Mind mapping stimulated the students' motivation and interest; made the students more active in joining the class and paid attention to the lesson; made writing became enjoyable and alive; and made the students' good habit in writing.

The following are some suggestions which might be useful for teacher, the students, and educational institution. For
English teacher, mind mapping can be applied to improve students' writing. Teacher should be creative in designing teaching and learning process using mind mapping. I suggest the teacher should plan extra time in each activity, especially in discussing the topic and revising their writing. In implementation, the students need much time to do these activities. The teacher also should often use this technique to change the students' habit in order that they are accustomed use the technique. For students, I suggest students to study hard. I also hope they will be creative in composing writing and use correct grammatical. They should collect much information and think that it will support their main idea or not. Therefore, their writing has a good content and their vocabulary range can be required. They also should change the handwriting style because it can influence the use of capitalization. They should try to revise their writing by reading again their writing to correct spelling, grammar, capitalization or punctuation. By revising, they also can add any information or delete inappropriate information. I hope the students do not consider writing as difficult task. By having good ability in writing, the students can give benefit for the writer and the reader. For Institution, the school should support the English teachers to improve the quality of their teaching by conducting routine workshop. Thus, they know variety of techniques that can be applied in their class and can improve their ability in teaching.

\section{BIBLIOGRAPHY}

Burns,Anne. (2001). Collaborative Action Research for English Language Teacher. United Kingdom: Cambridge University.

Clefford, Tony. (2002). Skills For Learning. Retrieved from http:// www.sharefile 
fengjun.googlecode.com/Tony.Buzan.t aking.notes.with.mind.map

DePorter, Bobbi and Mike Hernacki. (1992). Unleashing Genius in You. New York: Dell Publishing

Harris, John. (1993). Introducing Writing. London: Pinguin Group.

Hopkins, David. (1993). A Teacher's Guide to Classroom Research. London : St. Edmunsbury Press Ltd.

Ingeman, Marcus. (2008). The Power of Mind Mapping. Retrieved from http://www.FortuneWell.com

Langan, J. (2001). College Writing Skills with Readings. New York: Mc.GrawHill Companies, Inc.

Murley, Diane. (2007). Mind Mapping Complex Information. Retrieved from http://www.papers.ssrn. com

Nunan, David. (1996). The Self-directed Teacher. Cambridge: Cambridge University Press.

.(1998). Designing Task for the Communicative Classroom. Cambridge: Cambridge University Press.

Reid, Joy M. (1993). Teaching ESL Writing. New Jersey: Prentice Hall

Silberman, Mel. (1996). Active Learning: 101 Strategi Pembelajaran Aktif. Terjemahan Sarjuli et. Al. Yogyakarta: Pustaka Insan Madani.

Steele, Vanessa. (2005). Using Mind Map to Develop Writing. Retrieved from http://teachingenglish.org.uk/articles/u sing-mind-maps-develop-writing

Sudibyo, Bambang. (2006). Permendiknas No 23 Tahun 2006. Retrieved from http://akhmadsudrajat.files.wordpress. com/2012/01/nomor-23-tahun 2006.pdf

Widdowson, H.G. (1996). Teaching Language as Communication. London: Longmann.
Wycoff, Joyce. (2003). Menjadi Super Kreatif Melalui Metode Pemetaan Pikiran. Bandung : Kaifa. 